\title{
Prediction of moisture transfer parameters for convective drying of shrimp at different pretreatments
}

\author{
Marcus Vinicius da COSTA ${ }^{1}$, Aline Kazumi Nakata da SILVA ${ }^{1}$, Priscila Rodrigues e RODRIGUES ${ }^{1}$, \\ Luiza Helena Meller da SILVA ${ }^{1}$, Antonio Manoel da Cruz RODRIGUES ${ }^{1 *}$
}

\begin{abstract}
By the analytical model proposed by Dincer and Dost, the mass transfer parameters (moisture transfer coefficient and moisture diffusivity) of shrimp samples were determined. Three sets of drying experiments were performed with three samples of shrimp: without boiling (WB), boiled in salt solution (SB) and boiled in salt solution and subjected to liquid smoking process (SBS). The experiments were performed under controlled conditions of drying air at temperature of $60^{\circ} \mathrm{C}$ and velocity of $1.5 \mathrm{~m} / \mathrm{s}$. Experimental dimensionless moisture content data were used to calculate the drying coefficients and lag factors, which were then incorporated into the analytical model for slab and cylinder shapes. The results showed an adequate fit between the experimental data and the values predicted from the correlation. The boiling is the most recommended pretreatment, because provided a shorter drying time, with high values of moisture transfer coefficient and moisture diffusivity.
\end{abstract}

Keywords: shrimp drying; mass transfer; heat transfer; mathematical modeling.

Practical Application: The results showed that analytical technique developed by Dincer and Dost is an effective work tool and capable to calculate the moisture transfer coefficient and moisture diffusivity values for convective drying of shrimp, being then, of great significance for design and practicing engineers working in the drying industries.

\section{Nomenclature}

$D$ moisture diffusivity $\left(\mathrm{m}^{2} / \mathrm{s}\right)$

$t$ time (s)

$W$ moisture content by weight $(\mathrm{kg} / \mathrm{kg})$

$A_{1}$ Constant

$B_{1}$ Constant

Bi Biot number

Fo Fourier number

$S$ drying coefficient $(1 / \mathrm{s})$

$Y$ characteristics dimension

$y$ coordinate

$h_{m}$ moisture transfer coefficient $(\mathrm{m} / \mathrm{s})$

$G$ lag factor

$R^{2}$ coefficient of determination

$\chi^{2}$ chi-squared parameter

$L$ characteristic dimension (half-thickness for slab, radius for cylinder) (m)

$z$ coordinate
WB shrimp without boiling

$S B$ shrimp boiled in salt solution

SBS shrimp boiled in salt solution and subjected to liquid smoking process

Greek symbols

$\Phi$ dimensionless moisture content

$\mu_{1}$ root of the characteristic equation

Subscripts

$e$ equilibrium

$i$ initial

\section{Introduction}

Dried shrimp is one of the most important fishery products in north coast of Brazil (Pará State). Its price depends on shrimp qualities such as color, size, dryness and taste. Commonly the production of dried shrimp can be divided into two steps: boiling shrimp with salt water (in order to deactivate microorganisms) and then it is dried in the sun for 3-5 days. Although the open sun-drying method represents a low cost processing technique, 
it has limitations such as the control of the drying process and parameters, weather uncertainties and large drying area. Moreover, the products are prone to microbial and other contaminations that adversely affect the product quality in terms of color, nutrition, chemical composition and food hygiene (Koc et al., 2004; Ergunes \& Tarhan, 2006; Cárcel et al., 2007). Boiling also affects the quality of shrimp, that is, moisture content, protein content, color, and texture, and hence affects the quality of dried shrimp as well. For commercial producers, the ability to process continuously with reliability is important to satisfy their markets. The drying of food materials by the use of heated air has advantages on quality control, on achievement of hygienic conditions, and on reduction of product loss.

From an engineering point of view, it is important to develop a better understanding of the controlling parameters of this complex process. In order to improve the control of this unit operation, it is important to dispose of accurate models to simulate the drying curves under different conditions. Various complex heat and mass transfer models have been developed for a large number of food products (Kechaou \& Maalej, 2000; Teixeira et al., 2000; Yang et al., 2001; Krokida et al., 2002, 2004; Mayor \& Sereno, 2004). But in practical terms, there is a need for simple models verified by experimental data that will supply optimal solutions for the processes and it is not necessary to perform experimental tests in the real system.

The Fick's second law of diffusion has been the most widely investigated theoretical model in the drying processes of many foodstuffs. It can be used for many regularly shaped bodies such as spherical, cylindrical and rectangular products and commonly postulates that one-dimensional moisture movement occurs with uniform initial moisture distribution, constant diffusivity, negligible external resistance and without volume change.

Dincer \& Dost $(1995,1996)$ developed and evaluated an analytical model for studying the mass transfer in geometrically and irregularly shaped objects during the drying processes. New drying parameters ( $S$ - drying coefficients and $G$ - lag factors) were introduced based on a resemblance between drying and cooling profiles, both of which exhibit an exponential function with time. The analytical model was applied to wood samples (slab shaped) subjected to drying, with the results indicating that the model was capable of determining the moisture diffusivities and moisture transfer coefficients in a simple and accurate manner for practical applications, and would be beneficial to the relevant drying industries (Dincer, 1998).

By the use of the analytical model proposed by Dincer \& Dost (1995), the objective of this work is to determine the moisture transfer coefficient and the moisture diffusivity for shrimp subjected to different pretreatments and convective drying. In addition, as the shrimp has irregular shaped, correlations for slab and cylinder shapes were tested in this study to estimate the moisture transfer parameters.

\section{Materials and methods}

\subsection{Raw material}

The material tested in the present study was wild shrimp of the genus Macrobrachium amazonicum. Raw shrimp were caught off in the city of Belém (Pará State, Brazil) with different sizes.
The shrimps were placed in ice with an ice/shrimp ratio of 2:1 (w/w) and transported to the Laboratory of Food Technology of Federal University of Pará. Upon arrival, the shrimps were washed with potable water, graded and subjected to freezing and glazing process. The freezing was conducted by air blast freezing at $-30^{\circ} \mathrm{C}$ and $5 \mathrm{~m} / \mathrm{s}$ air velocity. Where at vigorous circulation of cold air enables freezing to proceed at a moderately rapid rate. In seafood industry, glazing is a technology widely used to protect the processed frozen shrimp during storage. This process consists in creating a water coating on the surface of frozen product by spraying or dipping the product in water. This coating reduces the rate of oxidation by excluding air from the product surface. In addition, it retards the freezer burn since the glaze will sublime instead of the tissue water; and another argument for implementing glazing is that if the product is subject to inadequate cold storage, the glaze will evaporate instead of the tissue water itself. After freezing and glazing process, shrimp samples were packaged and stored $\left(-18^{\circ} \mathrm{C}\right)$.

\subsection{Boiling shrimp and liquid smoking process}

Before each experiment, the shrimps were thawed at $5{ }^{\circ} \mathrm{C}$, beheaded and washed, to decrease the number of microorganisms to a safe level and to improve the appearance of final product. Afterwards, the samples were immersed in boiling salt solution $7 \%(\mathrm{w} / \mathrm{v})$ that was inserted in a stainless steel vessel of 2.6 litre of capacity for seven minutes and the mass ratio of shrimp to salt solution was of 1:5 on the weight basis (Niamnuy et al., 2007). The commercial size of classification $61 / 70$ (61 to 70 units of shrimp per pound) of raw beheaded shrimp was used in each boiling experiment. Afterwards, the samples were cooled at ambient air for $5 \mathrm{~min}$., deshelled and then subjected to liquid smoking process, where, the samples were immersed in liquid smoke solution $2 \%$ for 20 seconds.

\subsection{Drying experiments}

The drying processes were carried out in a convective tray dryer located in the Laboratory of Faculty of Food Engineering of Federal University of Pará. To conduct the drying experiments, the drying airflow and air temperature were kept constant at $1.5 \mathrm{~m} / \mathrm{s}$ and $60{ }^{\circ} \mathrm{C}$ respectively. The air velocity regulation was possible through controlling the speed of the blower motor by directly acting on a frequency modulation device (inverter). The air temperature was regulated through controlling the electric resistances by acting directly on the relative on/off relay switch. The air velocity and temperature were measured using anemometer hot-wire (model TAFR180, Instrutherm, Brazil; accuracy of $0.2-20.0 \pm 0.1 \mathrm{~m} / \mathrm{s}$ ) and microprocessor thermometers (model IP7520, IMPAC, Brazil; accuracy 0-400 $\pm 0.01{ }^{\circ} \mathrm{C}$ ), respectively. The drying conditions were selected based on the denaturation temperatures of myosin $\left(35\right.$ to $\left.60{ }^{\circ} \mathrm{C}\right)$ and actin ( 66 to $86^{\circ} \mathrm{C}$ ) which are the two major myofibrillar proteins of shrimp (Niamnuy et al., 2007; Brunton et al., 2006).

Three sets of drying experiments were performed with shrimps beheaded and deshelled. The first one, with shrimp without boiling (WB). The second set, with shrimp boiled in salt solution (SB). The third set, with shrimp boiled in salt solution and subjected to liquid smoking process (SBS). About $150 \mathrm{~g}$ of 
samples, were placed in a stainless-steel basket $(4.0 \times 20 \times 20 \mathrm{~cm})$, which was suspended on a balance (Ohaus, SP402, USA; accuracy of $\pm 0.01 \mathrm{~g}$ ), connected by a system interface (Ohaus, RS232, USA) to a personal computer (PC), which recorded and stored the weight changes in real time (measured every $10 \mathrm{~min}$ ) by means of the Microsoft Hyperterminal software until reaching constant weight (equilibrium condition).

\subsection{Characterization of the material}

The samples WB, SB and SBS were characterized according to the methodology described by AOAC (Association of Official Analytical Chemists, 1999): moisture (method 934.06), lipids (method 960.39), protein (method 960.52) and ash (method 923.03).

\subsection{Data analysis}

The moisture diffusion process observed during the drying operation is governed by Fick's second law. By adopting a number of assumptions, e.g.: there are finite internal and external resistances to moisture transfer within the solid; thermophysical properties of the solid and the drying medium are constant; the effect of heat transfer on the moisture loss is negligible; and the moisture diffusion occurs in one-direction (perpendicular to the slab surface), the transient moisture diffusivity equation in Cartesian coordinates and in dimensionless form can be written as Equations 1 and 2 (Dincer \& Hussain, 2002):

$$
\begin{aligned}
& \frac{\partial \Phi}{\partial t}=D \frac{\partial}{\partial y}\left(\frac{\partial \Phi}{\partial y}\right) \\
& \Phi=\frac{W-W_{e}}{W_{i}-W_{e}}
\end{aligned}
$$

Where $\Phi$ is the dimensionless moisture content, $\mathrm{t}$ is time (s), $D$ is moisture diffusivity $\left(\mathrm{m}^{2} / \mathrm{s}\right), y$ is the space coordinate measured from the center of the tray and $W$ is moisture content by weight as dry basis $(\mathrm{kg} / \mathrm{kg})$.

The Equation 1 is subjected to the following initial and boundary conditions:

$$
\begin{aligned}
& \Phi(y, 0)=1 \\
& \left(\frac{\partial \Phi(0, t)}{\partial z}\right)=0 \\
& -D\left(\frac{\partial \Phi(L, t)}{\partial z}\right)=h_{m} \Phi(L, t) \text { for } 0.1 \leq B i \leq 100, \Phi(L, t)=0 \text { for } B i>100
\end{aligned}
$$

The solution of the governing Equation 1 with the boundary conditions yields dimensionless center moisture distribution for regular shaped objects in the following form:

$\Phi=\sum_{n=1}^{\infty} A_{n} \cdot B_{n}$

The above solution can be simplified if the values of $\left(\mu_{1}^{2} F o\right)>1.2$ are negligibly small. Thus, the infinite sum in Equation 6 is well approximated by the first term only, i.e.:

$\Phi=A_{1} B_{1}$ where for slab shapes:

$$
A_{1}=\exp \left(\frac{0.2533 B i}{1.3+B i}\right)
$$

for cylindrical shapes:

$A_{1}=\exp \left(\frac{0.5066 B i}{1.7+B i}\right)$

and for all objects:

$$
B_{1}=\exp \left(-\mu_{1}^{2} F_{O}\right)
$$

Dincer \& Dost (1996) proposed the following exponential equation for the objects subject to drying, by introducing lag factor ( $G$, dimensionless) and drying coefficient $(S, 1 / \mathrm{s})$ :

$$
\Phi=G \exp (-S t)
$$

Drying coefficient shows the drying capability of an object or product per unit time and lag factor is an indication of internal resistance of an object to the heat and/or moisture transfer during drying. These parameters are useful in evaluating and representing a drying process. The values of the dimensionless moisture content can be obtained using the experimental moisture content measurements from Equation 2.

Both Equations 7 and 11 are in the same form and can be equated to each other by having $G=A_{1}$. The moisture diffusivity $(D)$ for slab and cylindrical shapes is given by the following equation (Dincer \& Dost, 1996):

$D=\frac{S Y^{2}}{\mu_{1}^{2}}$

where $Y$ is the characteristic dimension (half-thickness for slab, radius for cylinder) and $\mu_{1}$ is a root of solution to the moisture diffusivity, that is given as (Dincer \& Hussain, 2002):

for slab geometry,

$\mu_{1}=\operatorname{atan}(0.640443 B i+0.380397)$

for cylindrical geometry,

$\mu_{1}=\left(\left(\frac{3}{4.188}\right) \ln (6.796 B i+1)\right)^{1 / 1.4}$

In this solution, the dimensionless parameters used are the Biot number $(B i)$ and the Fourier number $(\mathrm{Fo})$, which are defined as:

$$
\begin{gathered}
B i=\frac{h_{m} \cdot Y}{D} \\
F o=\frac{D \cdot t}{Y^{2}}
\end{gathered}
$$

Where $h_{m}$ is the moisture transfer coefficient.

\subsection{Statistical analysis}

Analysis of variance (ANOVA) was conducted to determine the effect of variable factors on drying parameters. The parameters of the analytical model proposed by Dincer \& Dost (1996) (Equation 11) were estimated using the software Statistica for Windows 7.0 (StatSoft Inc., Tulsa, OK, USA). The fit quality of the proposed models for the drying kinetics data was estimated 
by means of the Chi-squared parameter $\left(\chi^{2}\right)$ and coefficient of determination $\left(R^{2}\right)$.

\section{Results and discussion}

Proximate compositions of the samples WB, SB and SBS are given in Table 1. The initial average moisture content of raw shrimp (WB) was $76.5 \pm 0.3 \%$, but decreased to $73.4 \pm 0.1 \%$ in the sample (SB) and $74.0 \pm 0.2 \%$ in the sample (SBS), due to the water loss during the boiling process $(p<0.05)$. Fat, protein and ash contents also increased after boiling process as compared to the fat, protein and ash content of raw shrimp (Table 1). No significant difference was found between the fat and ash contents of WB, SB and SBS samples ( $p>0.05)$.

The dimensionless moisture content values were regressed against the drying time in the exponential form of Equation 11, using the least squares curve fitting method and good fits were obtained for all drying conditions $\left(\mathrm{R}^{2}>0.98\right.$ and low $\chi^{2}$ values). This indicates that the main mechanism of water transport is diffusion and the diffusion equation (Equation 11) may be applied to the analysis of experimental drying data (Saravacos \& Maroulis, 2001). The drying curves are shown in Figure 1.

It is observed in Figure 1 that the pretreatments played a key role in the drying curves. The drying time for $\mathrm{WB}$ samples (480 min) was longer than the samples SBS (420 min) and SB (330 $\mathrm{min})$. This result is because of the heat-induced denaturation of proteins during boiling in salt solution, which in

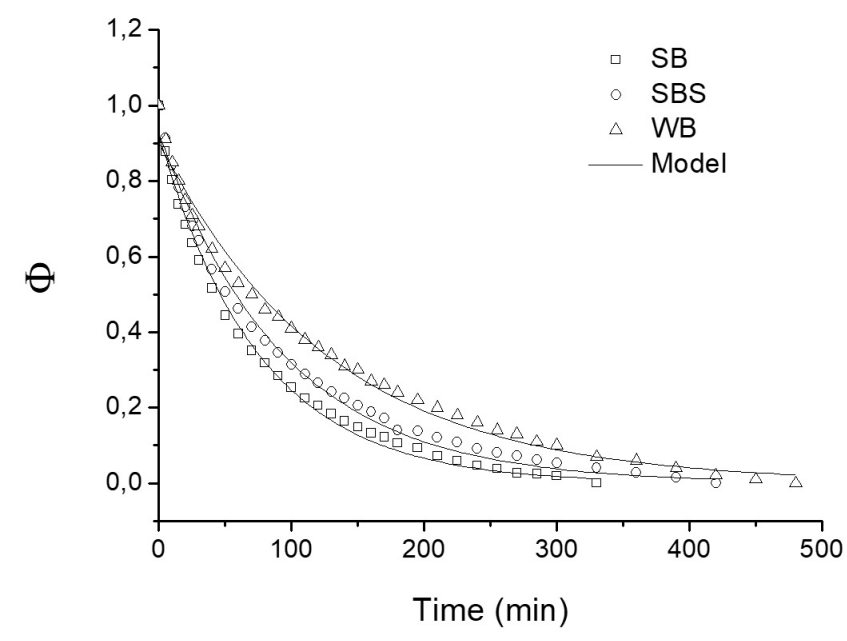

Figure 1. Experimental and predicted average dimensionless moisture content of shrimp boiled in salt solution ( $\square \mathrm{SB}$ ), shrimp boiled in salt solution and subjected to liquid smoking process ( $\circ$ SBS), and shrimp without boiling $(\triangle \mathrm{WB})$.

Table 1. Proximate composition of shrimp (wet basis).

\begin{tabular}{ccccc}
\hline Parameters & $\begin{array}{c}\text { Moisture } \\
(\%)\end{array}$ & $\begin{array}{c}\text { Fat } \\
(\%)\end{array}$ & $\begin{array}{c}\text { Protein } \\
(\%)\end{array}$ & $\begin{array}{c}\text { Ash } \\
(\%)\end{array}$ \\
\hline Raw shrimp & $76.5 \pm 0.3$ & $2.2 \pm 0.3$ & $19.7 \pm 0.1$ & $1.4 \pm 0.1$ \\
SB & $73.4 \pm 0.1$ & $2.3 \pm 0.1$ & $22.7 \pm 0.1$ & $1.6 \pm 0.2$ \\
SBS & $74.0 \pm 0.2$ & $2.2 \pm 0.20$ & $22.44 \pm 0.1$ & $1.7 \pm 0.2$ \\
\hline
\end{tabular}

turn led to lower water-holding capacity, of the shrimp samples. The drying time for samples SBS was longer than the samples $\mathrm{SB}$, though it has also been subjected to boiling. This behavior can be attributed to changes on the tissue structure of the shrimp caused by the incorporation of compounds, such as phenolic derivatives, carbonyls and organic acids, present in the composition of the extract smoke, which resulted in a type of coating of the surface of the shrimp, contributing in reduction of moisture movement.

The lag factors $(G)$ and drying coefficients $(S)$ were determined as presented in Table 2 . The drying coefficient $(S)$ is a parameter which indicates the drying capability of the solid object and has a direct effect on the moisture diffusivity. ANOVA showed significant differences $(p<0.05)$ in $S$ values caused by different pretreatments applied before drying. The value of the drying coefficient is highest for samples SB and was lowest for WB. These results demonstrate that boiling had a significant effect not only on the quality of shrimp, but also on the drying kinetics. Changes in the cellular structure of the material (denaturation and coagulation of protein) resulted in improvement in the rate of moisture removal from it. The values of $S$ obtained in this study are in the same range of the values found by Akpinar \& Dincer (2005) for eggplant slabs subjected to convective drying $\left(2.04 \times 10^{-4}\right.$ to $\left.3.82 \times 10^{-4} \mathrm{~s}^{-1}\right)$, by Corzo et al. (2008) for the drying of mango slices at different maturity stages $\left(2.49 \times 10^{-4}\right.$ to $\left.7.64 \times 10^{-4} \mathrm{~s}^{-1}\right)$ and by Bezerra et al. (2015) for the convective drying of passion fruit peel $\left(1.58 \times 10^{-4}\right.$ to $\left.3.12 \times 10^{-4} \mathrm{~s}^{-1}\right)$.

The lag factor $(G)$ provides an indication of the magnitude of the internal resistance to moisture transfer and has a direct effect on the moisture transfer coefficient as a function of the Biot number (Dincer \& Dost, 1996). For the three pretreatment, all lag factors $(G)$ were higher than 1 (Table 2), leading to the Biot number in the range $0.1<\mathrm{Bi}<100$, indicating the presence of internal and external resistance to moisture transfer.

After determining the lag factor, the Biot number for each experimental condition was calculated using Equations 8 or 9 , as appropriate. Posteriorly the values of $\mu_{1}$ for moisture transfer were determined from the simplified expressions for a slab and cylinder, Equations 13 and 14, respectively. The Biot numbers and $\mu_{1}$ values are shown in Table 3 . ANOVA showed significant differences $(p<0.05)$ in $B i$ values caused by different pretreatments applied before drying. The values of the Bi obtained in this study were of the same magnitude of that reported by several authors, such as those reported by Mrkic et al. (2007) for convective drying of broccoli (0.2060 to 0.3228 ), by Corzo et al. (2008) for the drying of mango slices ( 0.100 to 0.108 ), by Guiné et al. (2013)

Table 2. Lag factor and drying coefficient values obtained for shrimp.

\begin{tabular}{cccccc}
\hline \multirow{2}{*}{$\begin{array}{c}\text { Drying } \\
\text { condition }\end{array}$} & \multicolumn{2}{c}{ Model coefficients } & & \multicolumn{2}{c}{ Statistical parameters } \\
\cline { 2 - 3 } \cline { 5 - 6 } & $G$ & $S\left(s^{-1}\right)$ & & $R^{2}$ & $\chi^{2}$ \\
\hline WB & 1.0401 & $1.43 \times 10^{-4}$ & & 0.9932 & $6.20 \times 10^{-5}$ \\
SB & 1.0390 & $2.18 \times 10^{-4}$ & & 0.9857 & $1.27 \times 10^{-3}$ \\
SBS & 1.0380 & $2.76 \times 10^{-4}$ & & 0.9987 & $1.24 \times 10^{-4}$ \\
\hline
\end{tabular}

$W B$ - shrimp without boiling; $S B$ - shrimp boiled in salt solution; $S B S$ - shrimp boiled in salt solution and subjected to liquid smoking process; $G$ - lag factor; $S$ - drying coefficient; $R^{2}$ - coefficient of determination. 
for the drying of pears ( 0.1020 to 0.2026$)$ and by Bezerra et al. (2015) for drying of passion fruit peel (0.1018 to 0.3199).

Using the Equation 12, the moisture diffusivity $(D)$ was calculated. Posteriorly, using the Equation 15, the values of moisture transfer coefficient $\left(h_{m}\right)$ were determined. The values of $D$ and $h_{m}$ are shown in Table 4 . The knowledge of both the moisture diffusivities and mass transfer coefficients for the various systems is very important, as more complex mathematical models and correlations which can supply a deeper understanding of the drying processes require data on specific mass transfer parameters (Bezerra et al., 2015).

Values of $D$ (Table 4 ) for all drying conditions varied from $1.489 \times 10^{-8}$ to $2.960 \times 10^{-8} \mathrm{~m}^{2} / \mathrm{s}$ for slab, and $1.001 \times 10^{-8}$ to $2.050 \times 10^{-8} \mathrm{~m}^{2} / \mathrm{s}$ for cylinder. These values are within the normally expected range of $D\left(10^{-12}\right.$ to $\left.10^{-8} \mathrm{~m}^{2} / \mathrm{s}\right)$ for dehydrated foods (Zogzas et al., 1996; Giovanelli et al., 2002; Gely \& Santalla, 2007; Falade \& Solademi, 2010). An ANOVA test revealed significant influence of different pretreatments applied before drying $(p<0.05)$ in $D$ values. It was observed that the $D$ value for WB is lower $(p<0.05)$ than the SB and SBS, but there is no big difference $(p>0.05)$ in $D$ for the pretreatments SB and SBS.

The magnitude of the $D$ values (Table 4 ) is similar to those found by several authors for different food materials, such as those reported by Thorat et al. (2010) for drying of ginger slices ( $1.86 \times 10^{-8}$ to $4.78 \times 10^{-8} \mathrm{~m}^{2} / \mathrm{s}$ ), by Guiné et al. (2011) for convective drying of pumpkin $\left(4.08 \times 10^{-8}\right.$ to $\left.2.35 \times 10^{-7} \mathrm{~m}^{2} / \mathrm{s}\right)$, by Jurendić \& Tripalo (2011) for drying of baby food $\left(0.107 \times 10^{-8}\right.$ to $\left.53.1 \times 10^{-8} \mathrm{~m}^{2} / \mathrm{s}\right)$, by Shi et al. (2013) for drying of yacon slices $\left(1.092 \times 10^{-7}\right.$ to $7.388 \times 10^{-7} \mathrm{~m}^{2} / \mathrm{s}$ ) and by Harish et al. (2014) for drying of elephant foot yam $\left(4.44 \times 10^{-9}\right.$ to $\left.4.22 \times 10^{-8} \mathrm{~m}^{2} / \mathrm{s}\right)$. However, the values of $D$ obtained in this study were greater than that found by Doymaz (2011) for the drying of sweet potato slices, which ranging between $9.32 \times 10^{-11}$ to $1.75 \times 10^{-10} \mathrm{~m}^{2} / \mathrm{s}$. This variability depends on the types and conditions of experimental procedures used for determination of the $D$, data treatment methods, structure complexity of foods, drying temperature, physical or chemical

Table 3. Calculated mass transfer parameters $\left(B i\right.$ and $\left.\mu_{1}\right)$ of shrimp drying.

\begin{tabular}{cccccc}
\hline \multirow{2}{*}{$\begin{array}{c}\text { Drying } \\
\text { condition }\end{array}$} & \multicolumn{3}{c}{$B i$} & & \multicolumn{2}{c}{$\mu_{1}$} \\
\cline { 2 - 3 } \cline { 5 - 6 } & Slab & Cylinder & & Slab & Cylinder \\
\hline WB & 0.2384 & 0.1430 & & 0.4900 & 0.5977 \\
SB & 0.2245 & 0.1351 & & 0.4828 & 0.5801 \\
SBS & 0.2313 & 0.1389 & & 0.4862 & 0.5886 \\
\hline
\end{tabular}

$W B$ - shrimp without boiling; $S B$ - shrimp boiled in salt solution; $S B S$ - shrimp boiled in salt solution and subjected to liquid smoking process; $B i$ - Biot number; $\mu_{1}-$ root of the characteristic equation.

Table 4. Calculated mass transfer parameters $\left(D\right.$ and $\left.h_{m}\right)$ of shrimp drying.

\begin{tabular}{cccccc}
\hline \multirow{2}{*}{$\begin{array}{c}\text { Drying } \\
\text { condition }\end{array}$} & \multicolumn{2}{c}{$\mathrm{D} \times 10^{8}\left(\mathrm{~m}^{2} / \mathrm{s}\right)$} & & \multicolumn{2}{c}{$\mathrm{h}_{\mathrm{m}} \times 10^{7}(\mathrm{~m} / \mathrm{s})$} \\
\cline { 2 - 3 } \cline { 5 - 6 } & Slab & Cylinder & & Slab & Cylinder \\
\hline WB & 1.489 & 1.001 & & 7.113 & 2.863 \\
SB & 2.960 & 2.050 & & 13.290 & 5.539 \\
SBS & 2.305 & 1.573 & & 10.665 & 4.369 \\
\hline
\end{tabular}

WB - shrimp without boiling; $S B$ - shrimp boiled in salt solution; $S B S$ - shrimp boiled in salt solution and subjected to liquid smoking process; $D$ - moisture diffusivity; $h_{m}$ - moisture transfer coefficient. pretreatment and moisture content (Zogzas \& Maroulis, 1996; Dincer \& Hussain, 2002; Shi et al., 2013).

Values obtained of moisture transfer coefficient $\left(h_{m}\right)$ (Table 4) ranged between $7.113 \times 10^{-7}$ to $13.290 \times 10^{-7} \mathrm{~m} / \mathrm{s}$, and $2.863 \times 10^{-7}$ to $5.539 \times 10^{-7} \mathrm{~m} / \mathrm{s}$, respectively for slab and cylinder shape. These results are in the same range of those available by several authors for different foods and drying conditions, such as reported by Tsami \& Katsioti (2000) for drying of prune slices $\left(4.026 \times 10^{-7} \mathrm{~m} / \mathrm{s}\right)$, by Elbert et al. (2001) for drying of parboiled rice $\left(4.81 \times 10^{-7} \mathrm{~m} / \mathrm{s}\right)$, by Demirel \& Turhan (2003) for drying of banana slices $\left(6.0 \times 10^{-7}\right.$ to $\left.15.10 \times 10^{-7} \mathrm{~m} / \mathrm{s}\right)$, by Dincer \& Hussain (2004) for drying of onion slices (12.226 x 10-7 m/s), by Tripathy \& Kumar (2009) for drying of potato in cylindrical shape ( $1.61 \times 10^{-7}$ to $\left.4.17 \times 10^{-7} \mathrm{~m} / \mathrm{s}\right)$ and by Bezerra et al. (2015) for drying of passion fruit peel ( $4.530 \times 10^{-7}$ to $\left.8.702 \times 10^{-7} \mathrm{~m} / \mathrm{s}\right)$. This is an important drying parameter that depends on moisture diffusivity, viscosity, velocity of the fluid and the geometry of the transfer system (Saravacos \& Maroulis, 2001).

The ANOVA test showed significant differences $(p<0.05)$ in $h_{m}$ values caused by different pretreatments applied before drying. It was observed that the $h_{m}$ value for WB is lower $(p<0.05)$ than the SB and SBS. In the literature, determination of the moisture transfer coefficient for fishery products is scarce, in spite of it is extremely important in the evaluation of simultaneous mass and heat transfer processes.

\section{Conclusion}

The model developed by Dincer \& Dost (1995) is an effective means and capable to calculate the moisture transfer coefficient and moisture diffusivity values for convective drying of shrimp at different conditions of pretreatments applied before drying. It was observed that pretreatments applied had a significant effect on drying curves for shrimp samples. Therefore it is recommended boiling as a pretreatment before the drying of shrimp because it reduces the time and increases the rate of drying, due an increase in the rate of water evaporation, with high values of moisture transfer coefficient and moisture diffusivity.

\section{Acknowledgements}

The authors gratefully acknowledge the support provided by CAPES (PROCAD-NF UFPA/UFV process 21/2009), PROPESP/UFPA and CNPQ (Universal Project process 477183/2013-1).

\section{References}

Akpinar, E. K., \& Dincer, I. (2005). Moisture transfer models for slabs drying. International Communications in Heat and Mass Transfer, 32(12), 80-93. http://dx.doi.org/10.1016/j.icheatmasstransfer.2004.04.037.

Association of Official Analytical Chemists - AOAC. (1999). Official Methods of Analysis (15th ed., Vol. 2). Arlington: AOAC.

Bezerra, C. V., Silva, L. H. M., Corrêa, D. F., \& Rodrigues, A. M. C. (2015). A modeling study for moisture diffusivities and moisture transfer coefficients in drying of passion fruit peel. International Journal of Heat and Mass Transfer, 85, 750-755. http://dx.doi.org/10.1016/j. ijheatmasstransfer.2015.02.027. 
Brunton, N. P., Lyng, J. G., Zhang, L., \& Jacquier, J. C. (2006). The use of dielectric properties and other physical analyses for assessing protein denaturation in beef biceps femoris muscle during cooking from 5 to $85^{\circ} \mathrm{C}$. Meat Science, 72(2), 236-244. http://dx.doi.org/10.1016/j. meatsci.2005.07.007. PMid:22061550.

Cárcel, J. A., García-Pérez, J. V., Riera, E., \& Mulet, A. (2007). Influence of high intensity ultrasound on drying kinetics of persimmon. Drying Technology, 25(1), 185-193. http://dx.doi.org/10.1080/07373930601161070.

Corzo, O., Bracho, N., Alvarez, C., Rivas, V., \& Rojas, Y. (2008). Determining the moisture transfer parameters during the airdrying of mango slices using biot-dincer numbers correlation. Journal of Food Process Engineering, 31(6), 853-873. http://dx.doi. org/10.1111/j.1745-4530.2007.00194.x.

Demirel, D., \& Turhan, M. (2003). Air-drying behavior of Dwarf Cavendish and Gros Michel banana slices. Journal of Food Engineering, 59(1), 1-11. http://dx.doi.org/10.1016/S0260-8774(02)00423-5.

Dincer, I. (1998). Moisture loss from wood products during drying-part i: moisture diffusivities and moisture transfer coefficients. Energy Sources, 20(1), 67-75. http://dx.doi.org/10.1080/00908319808970044.

Dincer, I., \& Dost, S. (1995). An analytical model for moisture diffusion in solid objects during drying. Drying Technology, 13(1-2), 425-435. http://dx.doi.org/10.1080/07373939508916962.

Dincer, I., \& Dost, S. A. (1996). Modeling study for moisture diffusivities and moisture transfer coefficients in drying of solid objects. International Journal of Energy Research, 20(6), 531-539. http:// dx.doi.org/10.1002/(SICI)1099-114X(199606)20:6<531::AIDER171>3.0.CO;2-6.

Dincer, I., \& Hussain, M. M. (2002). Development of a new Bi-Di correlation for solids drying. International Journal of Heat and Mass Transfer, 45(15), 3065-3069. http://dx.doi.org/10.1016/S00179310(02)00031-5.

Dincer, I., \& Hussain, M. M. (2004). Development of a new Biot number and lag factor correlation for drying applications. International Journal of Heat and Mass Transfer, 47(4), 635-658. http://dx.doi. org/10.1016/j.ijheatmasstransfer.2003.08.006.

Doymaz, I. (2011). Thin-layer drying characteristics of sweet potato slices and mathematical modelling. Heat and Mass Transfer, 47(3), 277-285. http://dx.doi.org/10.1007/s00231-010-0722-3.

Elbert, G., Tolaba, M. P., \& Suárez, C. (2001). Effects of drying conditions on head rice yield and browning index of parboiled rice. Journal of Food Engineering, 47(1), 37-41. http://dx.doi.org/10.1016/S02608774(00)00097-2.

Ergunes, G., \& Tarhan, S. (2006). Color retention of red peppers by chemical pretreatments during greenhouse and open sun drying. Journal of Food Engineering, 76(3), 446-452. http://dx.doi.org/10.1016/j. jfoodeng.2005.05.046.

Falade, K. O., \& Solademi, O. J. (2010). Modelling of Air drying of fresh and blanched sweet potato slices. International Journal of Food Science \& Technology, 45(2), 278-288. http://dx.doi.org/10.1111/j.13652621.2009.02133.x.

Gely, M. C., \& Santalla, E. M. (2007). Moisture diffusivity in quinoa (Chenopodium quinoa Willd.) seeds: Effect of air temperature and initial moisture content of seeds. Journal of Food Engineering, 78(3), 1029-1033. http://dx.doi.org/10.1016/j.jfoodeng.2005.12.015.

Giovanelli, G., Zanoni, V., Lavelli, V., \& Nani, R. (2002). Water sorption, drying and antioxidant properties of tomato products. Journal of Food Engineering, 52(2), 135-141. http://dx.doi.org/10.1016/S02608774(01)00095-4.
Guiné, R. P. F., Barroca, M. J., \& Silva, V. (2013). Mass transfer properties of pears for different drying methods. International Journal of Food Properties, 16(2), 251-262. http://dx.doi.org/10.1080/10942912.20 11.551864.

Guiné, R. P. F., Pinho, S., \& Barroca, M. J. (2011). Study of the convective drying of pumpkin (Cucurbita maxima). Food and Bioproducts Processing, 89(4), 422-428. http://dx.doi.org/10.1016/j.fbp.2010.09.001.

Harish, A., Rashmi, M., Murthy, T. P. K., Blessy, B. M., \& Ananda, S. (2014). Mathematical modeling of thin layer microwave drying kinetics of elephant foot yam (Amorphophallus paeoniifolius). International Food Research Journal, 21(3), 1045-1051.

Jurendić, T., \& Tripalo, B. (2011). Biot number - lag factor (Bi-G) correlation for tunnel drying of baby food. African Journal of Biotechnology, 10(59), 12676-12683. http://dx.doi.org/10.5897/ AJB11.112.

Kechaou, N., \& Maalej, M. (2000). A simplified model for determination of moisture diffusivity of date from experimental drying curve. Drying Technology, 18(4-5), 1109-1125. http://dx.doi. org/10.1080/07373930008917758.

Koc, A. B., Toy, M., Hayoglu, I., \& Vardin, H., (2004). Performance of a solar dryer used for red pepper drying. Journal of the Faculty of Agriculture, Kyushu University, 8(2), 57-65.

Krokida, M. K., Foundoukidis, E., \& Maroulis, Z. (2004). Drying constant: literature data compilation for foodstuffs. Journal of Food Engineering, 61(3), 321-330. http://dx.doi.org/10.1016/S0260-8774(03)00136-5.

Krokida, M. K., Maroulis, Z. B., \& Marinos-Kouris, D. (2002). Heat and mass transfer coefficients in drying: literature data compilation. Drying Technology, 20(1), 1-18. http://dx.doi.org/10.1081/DRT-120001363.

Mayor, L., \& Sereno, A. M. (2004). Modelling shrinkage during convective drying of food material: a review. Journal of Food Engineering, 61(3), 373-386. http://dx.doi.org/10.1016/S0260-8774(03)00144-4.

Mrkic, V., Ukrainczyk, M., \& Tripalo, B. (2007). Applicability of moisture transfer Bi-Di correlation for convective drying of broccoli. Journal of Food Engineering, 79(2), 640-646. http://dx.doi.org/10.1016/j. jfoodeng.2006.01.078.

Niamnuy, C., Devahastin, S., \& Soponronnarit, S. (2007). Quality changes of shrimp during boiling in salt solution. Journal of Food Science, 72(5), S289-S297. http://dx.doi.org/10.1111/j.1750-3841.2007.00349.x. PMid:17995744.

Saravacos, G. S., \& Maroulis, Z. B. (2001). Transport properties offood. New York: Marcel Dekker.

Shi, Q., Zheng, Y., \& Zhao, Y. (2013). Mathematical modeling on thinlayer heat pump drying of yacon (Smallanthus sonchifolius) slices. Energy Conversion and Management, 71, 208-216. http://dx.doi. org/10.1016/j.enconman.2013.03.032.

Teixeira, M. B. F., Tobinaga, S., \& Misawa, F. T. (2000). Some theoretical and experimental considerations on the thin-layer drying of fish crackers: product expansion assessment. Drying Technology, 18(1-2), 1-19. http://dx.doi.org/10.1080/07373930008917690.

Thorat, I. D., Mohapatra, D., Sutar, R. F., Kapdi, S. S., \& Jagtap, D. D. (2010). Mathematical Modeling and Experimental Study on ThinLayer Vacuum Drying of ginger (Zingiber Officinale R.) slices. Food and Bioprocess Technology, 5(4), 1379-1383. http://dx.doi. org/10.1007/s11947-010-0429-y.

Tripathy, P. P., \& Kumar, S. (2009). A methodology for determination of temperature dependent mass transfer coefficients from drying kinetics: Application to solar drying. Journal of Food Engineering, 90(2), 212-218. http://dx.doi.org/10.1016/j.jfoodeng.2008.06.025. 
Tsami, E., \& Katsioti, M. (2000). Drying kinetics for some fruits: Predicting of porosity and color during drying. Drying Technology, 18(7), 1559-1581. http://dx.doi.org/10.1080/07373930008917793.

Yang, H., Sakai, N., \& Watanabe, M. (2001). Drying model with nonisotropic shrinkage deformation undergoing simultaneous heat and mass transfer. Drying Technology, 19(7), 1441-1460. http://dx.doi. org/10.1081/DRT-100105299.
Zogzas, N. P., \& Maroulis, Z. B., (1996). Effective moisture diffusivity estimation from drying data. A comparison between various methods of analysis. Drying Technology, 14(7-8), 1543-1573.

Zogzas, N. P., Maroulis, Z. B., \& Marinos-Kouris, D. (1996). Moisture Diffusivity Data Compilation in Foodstuffs. Drying Technology, 14(10), 2225-2253. http://dx.doi.org/10.1080/07373939608917205. 